\title{
Socially Responsible Behaviour of Sales Staff: Evidence from Western Balkans Supermarkets
}

\author{
Radenko Maric ${ }^{1}$, Branislav Radnovic ${ }^{2}$, Dragan Duranovic ${ }^{1}$, Goran Vukmirovic ${ }^{1}$ \\ ${ }^{1}$ University of Novi Sad \\ Segedinski put st. 9-11, 24000 Subotica, Serbia \\ E-mail.radenko.maric@ef.uns.ac.rs,djuranovic@ef.uns.ac.rs,vgoran@ef.uns.ac.rs \\ ${ }^{2}$ Educons University \\ Vojvode Putnika st.87, 21208 Sr. Kamenica, Serbia \\ E-mail.branislav.radnovic@educons.edu.rs \\ cross $^{\text {ref }}$ http://dx.doi.org/10.5755/j01.ee.28.1.15764
}

\begin{abstract}
The aim of this paper is to analyse and define the nature of indicators regarding socially responsible behaviour of sales staff in supermarkets in the region of the Western Balkans. Data in the research is collected electronically through a questionnaire, on a sample of 977 consumers in the largest supermarkets on the Western Balkans market. Chi-square test, $P$ value test and contingency $(C)$ coefficient were used to test the hypotheses and interpret results. The findings showed that differences between the indicators of social responsibility are not statistically significant, depending on the retailers where products are sold. Indicators show a statistically significant dependence of the countries, observed at the level of the region of Western Balkan countries that are members of the EU and transition countries outside the EU. Analysis of indicators of socially responsible behaviour of sales staff is significant in practice: a) it can assist the management of trading companies in defining and creating a socially responsible workplace and a seller who will meet consumers' needs and desires in a socially responsible manner; $b$ ) it provides the management of supermarkets from transition countries the insight into indicators that should be developed and strengthened in order to be competitive in the retail sector of the developed EU countries. Guidelines for future research are provided in the paper.
\end{abstract}

Keywords: Retail, Trade, Socially Responsible Behaviour, Supermarkets, Human Resource, EU Countries.

\section{Introduction}

Trade, especially the retail sector, is a service activity that causes an interactive relationship between buyers and sellers, and thus it is necessary that both parties are satisfied with the final transaction (Castaldo, Perrini, Misani, \& Tencati, 2009). The research results by Banerjee (2008) show that the concept of social responsibility applied by modern service companies directly reflects higher satisfaction of all participants in the sales transactions. The results of other studies (Salmones, Crespo \& Bosque, 2005) go in this favour, and clearly show the concept of social responsibility implemented by the management of service companies implies the growth in sales and transactions, as well as greater customer satisfaction with the transaction result. Customers are more motivated to purchase products and services from companies that behave socially responsible (Becker-Olsen, Cudmore \& Paul, 2006). Recent studies (Green \& Peloza, 2014) confirm the found results and indicate that consumers opt for re-purchase and re-consumption of goods and services if the behaviour of the sales staff in the final act of sales is recognized as socially and morally responsible. Other studies show a high degree of direct correlation between consumer satisfaction and socially responsible conduct of sales staff (Dul, Bhattacharya \& Sen, 2010).

The need for doing research on social responsibility in the retail sector of the Western Balkans stems from the fact that it is a rapidly growing sector of economic activity with the share in the total GDP in the analysed countries ranging between 15 and $18 \%$, and in the total number of employees from 8 to $11 \%$. The number of registered retailers is between $33 \%$ and $39 \%$ of the total number of legal entities, with over $20 \%$ share in the total revenue of the Western Balkans countries (Koncar \& Maric, 2015). In addition, the region of the Western Balkans is interesting for research because of the great economic, commercial, cultural and political differences between countries. Western Balkans comprises developed EU Member States (Slovenia and Croatia), and the countries that are in the process of transition and accession to the EU (Serbia, Bosnia, Montenegro and Macedonia) and are characterized by a low living standard (GDP growth from $-3.1 \%$ to 1.4 $\%$ ), high unemployment rate (over $19.2 \%$ ), double-digit inflation rate (over $11 \%$ ), low average net salary (about $350 €)$, etc. These are the reasons why particular attention should be paid to the retail sector of the Western Balkans, in particular the analysis of how to further increase profitability and business success of retailers by achieving maximum customer satisfaction and loyalty in a socially responsible manner.

Therefore, the basic research problem is to precisely define how important to consumers in the Western Balkans is social responsibility and whether the differences that appear in indicators are random or statistically significant, given the regions, countries and retailers where final sale and purchase are made. The main objectives of the paper 
are: (a) based on the literature and related research, to analyse and clarify indicators that make up the concept of socially responsible conduct in the retail sector, and (b) to test the actual significance of each individual indicator empirically. The obtained results and performed tests make the retail managers aware of the real impact of the analysed indicators. They can thus shape socially responsible workplace and profile a socially responsible salesperson who will responsibly undertake all business decisions and activities relating to costumers and market. As confirmed by the research conducted by Berber, Susnjar, Slavic \& Baosic (2014), companies with a built concept of social responsibility are more efficient and show better results in the implementation of HRM practices. Such established system within an organization results in higher loyalty of consumers to the subject seller, meaning they will again choose to buy products and services of that supermarket, and thus directly affect its profitability, market share and competitiveness.

The paper is structured as follows. The introduction is followed by literature review summarizing the most important theoretical aspects of how important social responsibility is, especially with regard to service industries. The literature review provides the basis for setting null research hypotheses. The methodology shows the research sample and the basic testing stages using Chisquare test, $P$ value test and Contingency $(C)$ coefficient test. Research results and testing of hypotheses are presented in the Results chapter. Discussions on obtained results are covered in the Discussion chapter. The test results are used for profiling of a socially responsible salesperson. Finally, the conclusion summarizes the most important results of the study and provides suggestions for future research.

\section{Literature Review}

\section{Socially Responsible Behaviour}

Socially responsible business behaviour can be interpreted in several ways. Some authors think social responsibility encompasses economic, legal, ethical and philanthropic responsibilities (Kim \& Reber, 2008), while others see it as management based on creating balance between economic, social, moral and environmental objectives (Berber, Susnjar, Slavic \& Baosic, 2014). Corporate social responsibility is in fact a moral commitment to the work that contributes to the economic development of a company and improves life quality of employees, local community, the public, and the society as a whole (Patrus, Carvalho Neto, Coelho, \& Sousa Teodosio, 2013). However, complex interpretation of social responsibility prompted the authors to distinguish between four structural parts of this concept: Part 1 knowledge of basic moral and philosophical principles, Part 2 - all business activities of company's management must be aligned with the interests of the society, Part 3 business policy and business strategy must be founded on ethical and moral values, and Part 4 - science, religion and social issues should be significantly represented in corporate management, planning and setting of business goals (Garriga, 2000). Similarly, socially responsible business behaviour is viewed as employee's sense of identification with the company, job and consumers (market) (Molica, Carvalho Neto, \& Goncalves, 2008). This sense is expressed in employees' motivation to make efforts in their work, to take responsibility and be willing to learn how to do their job in the best possible way, taking into account the profitability of the company, as well as the satisfaction of consumers, markets and the public. Socially responsible business behaviour can actually be regarded as the management's philosophy and its way of thinking, where employees' responsibility cannot be exclusively related to the company (corporate resources), but must be extended to consumers, the public, society and the state (Johansson \& Neilsen 2012). Through their actions, employees should not be guided only by corporate interests and profitability, but take into account the public "good" in terms of meeting the needs, interests and desires of consumers and markets (Demetriades \& Auret, 2014). In addition to the above, Thomson, Arthur \& Strickland (2008) point out that the companies that are truly committed to socially responsible management, are making efforts in making socially and morally responsible behaviour a fundamental component of their business culture. The importance of incorporating social and moral standards in business activities represents a positive impact on long-term strategic success of a company. This will foster the kind of integrity that implies customer's respect.

\section{Socially Responsible Behaviour in Retail Sector}

Socially responsible behaviour is very important in retail sector, where profitability and business results largely depend on employees who directly provide services to end users. If applied, the concept of social responsibility directly affects the quality of service and final sales act, but also consumers' satisfaction and loyalty to a trading company (Besley \& Ghatak, 2007). Corporate social responsibility could be observed as set of indicators that employees should get familiar with and apply in order to act in socially responsible manner. In this context, many studies emphasize the importance of the following key indicators of social responsibility in the service sector: 1) Honesty in sales transactions - which means that sellers must not in any way exert pressure or persuasion on consumers to buy certain products or services. Also, sellers must not resort to deceptive sales techniques " $2+1$ " (for example: buy two products and get the third one for free, etc.); forced promotion of products from a favored manufacturer, false discounts, etc. (Snider, Hill, \& Martin, 2003). Besley \& Ghatak (2007) consider honesty as the most important component of a socially and morally responsible employee, who enables profit for the company; 2) Fair relationship with consumers - which means that sellers need to treat consumers with courtesy, respect, patience and hospitality (Sankar \& Bhattacharya, 2001). The research by Ndubisi (2007) show that trust, kindness, devotion and respect for customers significantly contribute to their loyalty. 3) Timely and accurate information sellers are required to provide consumers with necessary, timely and accurate information about the manufacturer, product and service, price, warranty terms, benefits from payment, period for complaints, etc., and thus enable them a safe choice of purchase (McDonald \& Rundle-Thiele, 2008). Salmones et al. (2005) sees the lack of accurate, 
timely, complete and relevant data and information as the greatest threat to loyalty towards company, its products and services on the market. 4) Cultural behaviour - refers to the individual interpretation of sellers' behaviour and attitude towards consumers, such as: pleasant tone of voice, courteous addressing, good manners and gestures, assistance in choosing a product, etc. (Molica et al., 2008). Salacuse (1998) recognizes cultural indicators as the most important factors for establishing good business relations between parties in sales transactions. 5) Respecting moral codes - refers to seller's obligation to act according to the Categorical imperative. The Categorical imperative or the highest "moral law" is defined by the German philosopher Kant and it reads: "Act in such a way that you treat humanity, whether in your own person or in the person of any other, never merely as a means to an end, but always at the same time as an end". In other words, according to Kant, seller's moral obligation is to regard any consumer as a goal, not only as a means to achieve corporate objectives. 6) Compliance with legal and statutory norms implies sellers' obligation to know their powers, legal responsibilities, to behave as specified in the company's statute, to know their duties and responsibilities. In his research, Eisenberg (1999) shows that it is impossible to talk about the "good" work organization within the company without respecting laws and statutes as fundamental drivers of all business activities aimed at consumers and the market. 7) Collegiality and communication - implies a good relationship, information exchange and two-way communication with colleagues, aimed at obtaining better information on product range, product quality and durability, payment methods, current promotions and discounts, etc. (Dul, Bhattacharya \& Sen, 2010).

\section{Socially Responsible Behaviour in Western Balkans}

End of the first and beginning of the second decade of the 21 st century was marked by a period of recession and deep economic crisis, which also hit the economies of the Western Balkans. This is supported by the negative macroeconomic indicators, such as: growth in gross domestic product (GDP) at the rate of $-0.5 \%$; increase of unemployment rate of over $20 \%$, or more than 2.5 million unemployed people at the end of 2014; increase in the inflation rate from 5 to $10 \%$; the growth of public debt over $55 \%$ of the total gross domestic product; instability, significant fluctuations and continuing weakening of the domestic currency against euro, etc. (Koncar \& Maric, 2015). Such indicators leave little room to retailers in the Western Balkan region to wholeheartedly commit to corporate social responsibility. As concluded by VemicDjurkovic et al. (2013), the only obligation of companies in the transition countries has become how to survive in the market, and only then the management can think about the interests of customers, the actual social needs and public "good". The authors (Koncar \& Maric 2015; VemicDjurkovic et al. 2013; Kuzmanovic, \& Vukovic, 2010) state that as a consequence of such market status, transition economies show cases of employees put under pressure by company management to knowingly violate the standards of corporate social responsibility in order to achieve better business results, market share and corporate goals.
Pressure on employees is most pronounced in the SME sector, where the owners are just the ones that determine the behaviour and acts of employees to potential customers and the market. They justify putting pressure on employees with survival of the company in the market (VemicDjurkovic et al., 2013)

The beginnings of corporate social responsibility in the Western Balkans are related to 2005, when the leading organization in the field of social communication - Smart Collective, conducted a survey of the levels of engagement of companies in terms of corporate social responsibility in the Western Balkans. The research results show that the main problem of transition countries of the Western Balkans is the lack of awareness of the importance of CSR in the market and the long-term benefits of opting for such a business strategy (Kuzmanovic \& Vukovic, 2010). Later research (Koncar \& Maric, 2015; Vemic-Djurkovic et al., 2010) show that the importance of the concept of social responsibility to consumers in the Western Balkans is reflected in the fact that consumers show greater loyalty to companies that are recognized as socially responsible. When selecting the brand in the process of purchasing, consumers prefer products or use the services of socially responsible companies, estimating that they will have a smaller qualitative risk, which will increase perceptual benefit. The surveys show that consumers think Telekom Serbia, Hemofarm Stada, etc. are the most socially responsible companies in the Western Balkans (CSR Award by the Serbian Chamber of Commerce 2014 and 2012), but these are also the companies with the highest market share in the segment of telecommunications services, pharmaceutical products, etc. In other words, consumers' loyalty is proportionate to market share of socially responsible companies in the Western Balkans. It should be emphasized that because of the withdrawn international donations and funds from the market of the Western Balkans, it is important to come up with new approaches for financing the corporate social responsibility concept, such as: tax cuts for companies that operate according to the principles of social responsibility, planned items in the budget for companies committed to public «good», humanitarian dinar, promotion of companies that consumers find socially responsible, etc. (Kuzmanovic \& Vukovic, 2010). Except for the above, extensive and serious scientific research on social and corporate responsibility in the service sector and retail sales in the region of the Western Balkans is not realized. Therefore, this study represents a pioneering step in raising awareness among employees and consumers about the need to implement the concept of corporate social responsibility in the retail sector of the Western Balkans, defining the indicators that shape specific indicator and establishing theoretical foundations for future research.

\section{Global Effect on Socially Responsible Behaviour}

Compared with the Western Balkans, several studies were conducted in the global market that pointed to significance of the analysed indicators on the socially responsible behaviour in the retail sector. The results of the research conducted by Snider, Hill and Martin (2003) on a sample of U.S.A. top 50 and non - U.S.A. top 50 multinational firms show that the importance of social 
responsibility indicators in the services sector is more pronounced for U.S.A. companies, unlike the rest of the world, and that the behaviour of employees is directly correlated with the social responsibility philosophy promoted by the top management of the company. Cultural behaviour, fair attitude towards clients, etc. are distinguished as the most important indicators of social responsibility in the U.S. companies. The research carried out in the UK (Jones, Comfort \& Hillier, 2007) and Sweden (Andersen \& Tage Skjoett-Larsen 2009) point out that customers in the retail sector show greater loyalty to retailers that apply the concept of social responsibility. However, the basic principles of this concept vary greatly depending on retailers that have different approach to social responsibility and commitment to customers. Other studies (Gugler \& Shi, 2008) show that under-developed countries and regions pay less attention to social responsibility and that there are significant differences in the indicators that form the socially responsible behaviour between developed countries and developing countries. In developed countries (USA \& EU), consumers assign greater significance to fair attitude towards clients, cultural behaviour and business etiquette of a seller, as opposed to developing countries, where the emphasis is on precise information about characteristics of products and services, honesty, etc. (Andersen \& Tage Skjoett-Larsen 2009; Gugler \& Shi, 2008; Jones, Comfort \& Hillier, 2007; Snider, Hil \& Martin, 2003). Consequently, the market of the Western Balkans is a good sample to test these claims, and to define the indicators of corporate social responsibility in the retail sector. Taking into account the presented aspects, the following research questions can be posed: $\mathrm{RQ}_{1}$ : How do the consumers in the Western Balkans react to indicators of corporate social responsibility? $\mathrm{RQ}_{2}$ : Are the differences in indicators statistically significant depending on retailer, country and region? $\mathrm{RQ}_{3}$ : Define the impact of each indicator of socially responsible behaviour of sales staff in retail sector based on obtained results.

\section{Methodology}

\section{Aim and Hypotheses}

The main aim of the research is to analyse and define the significance of the indicators of socially responsible behaviour of sales staff in the retail sector and to determine the dependence of the social responsibility indicators on retailers where a final sale and purchase are made, countries and regions in which they operate. On the basis of such a defined research objective, three basic research hypotheses are set:

- Null hypothesis $\mathrm{H}_{1}$ reads: Indicators of socially responsible behaviour of sales staff are independent of retailers in which they provide services. The hypothesis implies testing whether the differences in indicators of socially responsible behaviour of sales staff are random regarding retailers where final purchase and sale are performed between buyers and consumers that evaluate the service. If the test reveals statistically significant differences, then the alternative hypothesis $\mathrm{H}_{\mathrm{a} 1}$ is accepted and reads: Indicators of socially responsible behaviour of sales staff and retailers are dependent characteristics.

- Null hypothesis $\mathrm{H}_{2}$ reads: Indicators of socially responsible behaviour of sales staff in retailers are independent of analysed countries in the Wester Balkans. The hypothesis implies testing whether the differences in indicators of socially responsible behaviour of sales staff are random regarding a country of the Western Balkans where a retailer operates. If the test reveals statistically significant differences, then the alternative hypothesis $\mathrm{H}_{\mathrm{a} 2}$ is accepted and reads: Indicators of socially responsible behaviour of sales staff and the analysed country of the Western Balkans where a retailer operates are dependent characteristics.

- Null hypothesis $\mathrm{H}_{3}$ reads: Indicators of socially responsible behaviour of sales staff in retailers are independent of the region of the Wester Balkans countries that are EU countries and not EU countries. The hypothesis implies testing if the indicators of socially responsible conduct are evaluated identically in economically developed region of the Western Balkans in EU (Slo., Cro.) with relation to other countries that are in the EU accession process (Srb., B\&H, Mne., Mkd.). If the test reveals statistically significant differences, then the alternative hypothesis $\mathrm{H}_{\mathrm{a}}$ is accepted and reads: Indicators of socially responsible behaviour of sales staff in retailers and the region of the Wester Balkans countries that are EU countries and not EU countries are dependent characteristics.

\section{Method}

The proposed hypotheses will be tested based on the Chi-square test of independence and the P-value test. Contingency coefficient $(C)$ will be used as an additional mechanism to confirm the accuracy of the conducted testing and verification of the correlation between the tested characteristics. It is necessary to determine whether the value of contingency coefficient is closer to the maximum (Cmax) or zero. The closer the resulting value of the contingency coefficient to Cmax., the stronger and more intense the relationship between the observed characteristics (Sullivan, 2007).

\section{Participants}

This study was conducted among 977 consumers evenly distributed at five age groups (20-30 yrs., 30-40 yrs., 40-50 yrs., 50-60 yrs., and 60+; average age $\mathrm{Srb}=41,5 ; \mathrm{B} \& \mathrm{H}=52,1 ; \mathrm{Mne}=45,2 ; \mathrm{Slo}=49,4 ; \mathrm{Cro}=50,8)$. The study equally covers both sexes of the respondents (female $=507(52 \%)$, male $=470(48 \%)$ ). An identical number of subjects was tested in Slovenia $(n=190)$, Croatia $(n=201)$, Serbia $(n=202)$, Bosnia and Herzegovina $(n=189)$ and Montenegro $(n=195)$. This research sample is appropriate and belongs to the category of large statistical samples. The representativeness of the research was provided by the fact that testing of sales staff was conducted in the four largest retail chains in Serbia (Delhaize Maxi $n=59$, Idea $n=55$, DIS $n=52$, Roda $n=36$ ), three largest retail chains in Croatia (Konzum $n=67$, Spar $\mathrm{n}=66$, Mercator $\mathrm{n}=68$ ) and Slovenia (Mercator $\mathrm{n}=61$, Spar $\mathrm{n}=65$, Tus $\mathrm{n}=64$ ) and two largest retail chains in Bosnia and Herzegovina (Konzum $\mathrm{n}=98$, Bingo $\mathrm{n}=91$ ) and Montenegro (Voli $n=101$, Roda $n=94$ ). These retail chains, according to the report of Deloitte (2015), are the biggest retailers in the market of the Western Balkans. 


\section{Procedure}

Data necessary for the testing are collected electronically (using CAWI - Computer-assisted web interviewing) on the basis of an anonymous questionnaire comprising five questions in the period from September to December 2015. The electronic questionnaire was sent to the supermarkets, which forwarded the questionnaire to their customers from the existing contact database. Respondents were offered a list of already prepared indicators. Their task was to choose one indicator as the most important for the concept of socially responsible behaviour. The survey included service users in supermarkets in the market of the Western Balkans. The Western Balkans region comprises six countries: Serbia, Bosnia and Herzegovina, Montenegro, Croatia, Slovenia and Macedonia. Macedonia is not included in the sample due to the current political and economic instability and impossibility to successfully implement this study. A total of 1,500 questionnaires was sent, i.e. 300 to supermarkets in each of the analysed countries ( $\mathrm{Srb}$ - rate of return $r=67.3 \%$; $\mathrm{B} \& \mathrm{H}-$ rate of return $\mathrm{r}=63 \%$; Mne - rate of return $\mathrm{r}=65 \%$; Cro - rate of return $\mathrm{r}=67 \%$; Slo - rate of return $\mathrm{r}=63.3 \%$ ).

\section{Data Analysis}

For the processing and analysis of collected data, the statistical programs were used: 1) IBM SPSS Statistics 20 - software package for statistical analysis on social sciences and 2) Microsoft Excel 2010 Data Analysis. Established hypotheses were tested on the basis of nonparametric Chi-square test of independence of characteristics and $P$-value test. Contingency coefficient $(C)$ was used to determine the intensity and severity of dependence among the tested characteristics.

\section{Research Results and Analysis}

The following tabular presentation (Table 1) illustrates the detailed answers of respondents grouped according to the indicators, countries and supermarkets where testing was conducted.

The Results of Responses from Observed Supermarkets

Table 1

\begin{tabular}{|c|c|c|c|c|c|c|c|}
\hline Country & \multicolumn{7}{|c|}{ Indicators of socially responsible behaviour of sales staff } \\
\hline Serbia & $\begin{array}{l}\text { Honesty in } \\
\text { sales } \\
\text { transactions }\end{array}$ & $\begin{array}{c}\text { Fair treatment } \\
\text { of consumers }\end{array}$ & $\begin{array}{c}\text { Timely and } \\
\text { accurate } \\
\text { information }\end{array}$ & $\begin{array}{l}\text { Cultural } \\
\text { behaviour }\end{array}$ & $\begin{array}{c}\text { Acting in } \\
\text { accordance } \\
\text { with moral } \\
\text { codes }\end{array}$ & $\begin{array}{c}\text { Compliance } \\
\text { with legal } \\
\text { and statutory } \\
\text { norms }\end{array}$ & $\begin{array}{l}\text { Collegiality and } \\
\text { good business } \\
\text { communication }\end{array}$ \\
\hline Delhaize Maxi (n/F) & $11(18,64 \%)$ & $12(20,34 \%)$ & $15(25,42 \%)$ & $10(16,95 \%)$ & $5(8,47 \%)$ & $4(6,78 \%)$ & $2(3,39 \%)$ \\
\hline Idea $(\mathbf{n} / \mathbf{F})$ & $12(21,82 \%)$ & $10(18,18 \%)$ & $12(21,82)$ & $8(14,55 \%)$ & $4(7,27 \%)$ & $5(9,09 \%)$ & $4(7,27 \%)$ \\
\hline DIS (n/F) & $9(17,31 \%)$ & $12(23,08 \%)$ & $12(23,08 \%)$ & $9(17,31 \%)$ & $2(3,85 \%)$ & $6(11,54 \%)$ & $2(3,85 \%)$ \\
\hline Roda $(\mathbf{n} / \mathbf{F})$ & $6(16,67 \%)$ & $7(19,44 \%)$ & $8(22,22 \%)$ & $6(16,67 \%)$ & $2(5,56 \%)$ & $3(8,33 \%)$ & $4(11,11 \%)$ \\
\hline Total (n/F) & $38(18,81 \%)$ & $41(20,30 \%)$ & $47(23,27 \%)$ & $33(16,34 \%)$ & $13(6,44 \%)$ & $18(8,91 \%)$ & $12(5,94 \%)$ \\
\hline \multicolumn{8}{|l|}{$B \& H$} \\
\hline $\operatorname{Konzum}(\mathbf{n} / \mathbf{F})$ & $26(26,53 \%)$ & $20(20,41 \%)$ & $25(25,51 \%)$ & $8(8,16 \%)$ & $2(2,04 \%)$ & $10(10,20 \%)$ & $7(7,14 \%)$ \\
\hline $\operatorname{Bingo}(\mathbf{n} / \mathbf{F})$ & $25(27,47 \%)$ & $19(20,88 \%)$ & $20(21,98 \%)$ & $12(13,19 \%)$ & $5(5,49 \%)$ & $4(4,40 \%)$ & $6(6,59 \%)$ \\
\hline Total (n/F) & $51(26,98 \%)$ & $39(20,63 \%)$ & $45(23,81 \%)$ & $20(10,58 \%)$ & $7(3,70 \%)$ & $14(7,41 \%)$ & $13(6,88 \%)$ \\
\hline \multicolumn{8}{|l|}{ Montenegro } \\
\hline Voli (n/F) & $18(17,82 \%)$ & $19(18,81 \%)$ & $26(25,74 \%)$ & $13(12,87 \%)$ & $5(4,95 \%)$ & $12(11,88 \%)$ & $8(7,92 \%)$ \\
\hline Roda $(\mathbf{n} / \mathbf{F})$ & $25(26,60 \%)$ & $17(18,09 \%)$ & $23(24,47 \%)$ & $10(10,64 \%)$ & $4(4,26 \%)$ & $8(8,51 \%)$ & $7(7,45 \%)$ \\
\hline \multicolumn{8}{|l|}{ Croatia } \\
\hline Mercator (n/F) & $8(12,12 \%)$ & $18(27,27 \%)$ & $11(16,67 \%)$ & $11(16,67 \%)$ & $10(15,15 \%)$ & $5(7,58 \%)$ & $3(4,55 \%)$ \\
\hline Konzum (n/F) & $7(10,29 \%)$ & $20(29,41 \%)$ & $9(13,24 \%)$ & $11(16,18 \%)$ & $8(11,76 \%)$ & $7(10,29 \%)$ & $6(8,82 \%)$ \\
\hline $\operatorname{Spar}(\mathbf{n} / \mathbf{F})$ & $8(11,94 \%)$ & $21(31,34)$ & $8(11,94 \%)$ & $10(14,93 \%)$ & $9(13,43 \%)$ & $5(7,46 \%)$ & $6(8,96 \%)$ \\
\hline Total $(\mathbf{n} / \mathbf{F})$ & $23(11,44 \%)$ & $59(29,35 \%)$ & $28(13,93 \%)$ & $32(15,92 \%)$ & $27(13,43 \%)$ & $17(8,46 \%)$ & $15(7,46 \%)$ \\
\hline \multicolumn{8}{|l|}{ Slovenia } \\
\hline Mercator (n/F) & $6(9,84 \%)$ & $18(29,51 \%)$ & $6(9,84 \%)$ & $14(22,95 \%)$ & $8(13,11 \%)$ & $6(9,84 \%)$ & $3(4,92 \%)$ \\
\hline Tus (n/F) & $8(12,31 \%)$ & $20(30,77 \%)$ & $9(13,85 \%)$ & $11(16,92 \%)$ & $7(10,77 \%)$ & $5(7,69 \%)$ & $5(7,69 \%)$ \\
\hline $\operatorname{Spar}(\mathbf{n} / \mathbf{F})$ & $7(10,94 \%)$ & $19(26,69 \%)$ & $8(12,59)$ & $12(18,75 \%)$ & $8(12,50 \%)$ & $6(9,38 \%)$ & $4(6,25 \%)$ \\
\hline Total (n/F) & $21(11,05 \%)$ & $57(30,00 \%)$ & $23(12,11 \%)$ & $37(19,47 \%)$ & $23(12,11 \%)$ & $17(8,95 \%)$ & $12(6,32)$ \\
\hline Total (WB) & 176 & 232 & 192 & 145 & 79 & 86 & 67 \\
\hline Frequency $(\mathbf{F})$ & $18,01 \%$ & $23,75 \%$ & $19,65 \%$ & $14,84 \%$ & $8,09 \%$ & $\mathbf{8 , 8 0 \%}$ & $6,86 \%$ \\
\hline
\end{tabular}

Source: Author

The results of empirical research show that the highest percentage $(n=232$ or $23,75 \%)$ of buyers in analysed supermarkets in the Western Balkans believes that correct attitude towards and appreciation of customers is the most important feature of socially responsible behaviour of the seller. Interestingly, this indicator was chosen by a high number of respondents in the Western Balkan countries that are EU members (Cro $n=59$ or $29,35 \%$ and Slo $n=57$ or $30,00 \%$ ), while in other countries it ranks as second (Srb $n=41$ or $20,30 \%)$, or third $(B \& H n=39$ or $20,63 \%$ and Mne $\mathrm{n}=36$ or $18.46 \%)$. The second rated factor ( $\mathrm{n}=192$ ili 19,65\%) is timely and accurate information provided to potential customers. The indicator is estimated as the most important in Serbia ( $\mathrm{n}=47$ or $23,27 \%)$ and Montenegro ( $\mathrm{n}=49$ or 25,13$)$, while it takes second place in Bosnia and Herzegovina ( $\mathrm{n}=45$ or $23,81 \%$ ). Customers in the Western Balkan countries that are EU members (Slovenia and Croatia) attached less importance to this indicator, so it is on the third place (Slo $\mathrm{n}=23$ or $12,11 \%$; Cro $n=28$ or $13.93 \%$ ). In the total survey sample, the 
indicator Honesty in sales transactions holds third place $(\mathrm{n}=176$ or $18,01 \%)$, while the indicator of cultural behaviour is at fourth place $(\mathrm{n}=145$ ili $14,84 \%)$. The significance of cultural behaviour as an indicator of social responsibility is particularly emphasized in the EU countries (Cro $n=32$ or $15,92 \%$ and Slo $n=37$ or $19,47 \%$ ), while in other countries, it is in fourth place. Respondents attach lower significance to the legal norms $(n=86$ or 8,80 $\%)$, moral codes $(n=7$ or $8,09 \%)$ and collegiality $(n=67$ or $6,86 \%)$.

Table 2 presents the necessary data for testing the hypothesis $\mathrm{H}_{1}$ of independence indicator of socially responsible behaviour of sales staff and retailers in the analysed countries of the Western Balkans. The analysis sets the indicators of social responsibility as dependent characteristics, while supermarkets are independent characteristics. The value of Chi-square statistics and Pvalue statistics are presented in the following way.

Table 2

Chi-Square tests (sample of analysed WB countries)

\begin{tabular}{|l|c|c|c|c|}
\hline & Pearson Chi-Square & \multicolumn{2}{|c|}{$\chi_{(\alpha=0,01 ; 0,05 ; d f)}^{2}$} & P-value \\
\hline Serbia & $5,647^{*}$ & 33,805 & 28,869 &, $997^{*}$ \\
\hline B \& H & $5,083^{*}$ & 16,812 & 12,592 &, $533^{*}$ \\
\hline Montenegro & $2,555^{*}$ & 16,812 & 12,592 &, $862^{*}$ \\
\hline Croatia & $2,761^{*}$ & 26,217 & 21,026 &, $997^{*}$ \\
\hline Slovenia & $6,045^{*}$ & 26,217 & 21,026 &, $914^{*}$ \\
\hline
\end{tabular}

$* \mathrm{H}_{1}$ is accepted

Test results show that in each of the analysed countries of the Western Balkans, the requirement $\chi_{0}^{2}<\chi_{(\alpha, d f)}^{2}$ is met, it means that null research hypothesis $\mathrm{H}_{1}$ is accepted and it can be concluded that the indicators of social responsibility are independent of retailers. That is, differences in indicators of social responsibility of sales staff are random, depending on the retailer where final purchase and sale are performed. As the $\mathrm{H}_{1}$ is accepted there is no need for further testing and calculating the contingency coefficient. Conclusions of testing are confirmed by $P$-value test, which shows strong evidence against $\mathrm{H}_{\mathrm{a} 1}$ since $\mathrm{P}>0,05$ is found for each country. The following Table 3 shows the same values grouped at the level of EU countries and not EU countries of the Western Balkans.

Table 3

Chi-Square Tests (Sub-Sample: EU Countries and Not EU Countries of WB)

\begin{tabular}{|l|c|c|c|c|}
\hline & Pearson Chi-Square & \multicolumn{2}{|c|}{$\chi_{(\alpha=0,01 ; 0,05 ; d f)}^{2}$} & P-value \\
\hline $\begin{array}{l}\text { Not EU } \\
\text { countries }\end{array}$ & $21,3^{*}$ & 63,691 & 55,758 &, $997^{*}$ \\
\hline $\begin{array}{l}\text { EU } \\
\text { countries }\end{array}$ & $6,163^{*}$ & 50,892 & 43,773 &, $999^{*}$ \\
\hline
\end{tabular}

$* \mathrm{H}_{1}$ is accepted

The results of Chi-square test on a sample of EU countries and not EU countries show that $\mathrm{H}_{1}$ is accepted because the requirement $\chi_{0}^{2}<\chi_{(\alpha, d f)}^{2}$ is met for both groups of countries, which confirms the conclusion that the differences between in indicators of social responsibility of sales staff and retailers are random. Accepting the hypothesis $\mathrm{H}_{1}$ is confirmed by the ratio $\mathrm{P}>0,05$. In the next step, the second research hypothesis $\mathrm{H}_{2}$ is tested on independence of indicators of corporate social responsibility of the Western Balkan countries in which a retailer operates. At this stage of testing, indicators of social responsibility are set as dependent characteristics, while the Western Balkan countries are independent characteristics. Necessary data illustrates the following tabulation (Table 4).

Table 4

Chi-Square tests (the overall sample of the Western Balkans)

\begin{tabular}{|l|c|c|r|r|}
\hline & Pearson Chi-Square & \multicolumn{2}{|c|}{$\chi_{(\alpha=0,01 ; 0,05 ; d f)}^{2}$} & $P$-value \\
\hline Western Balkans & $72,18^{* *}$ & 42,980 & 36,415 &, $000^{* *}$ \\
\hline$* * \mathrm{H}_{2}$ is rejected
\end{tabular}

Table 4 shows that at the level of the entire Western Balkans market, the requirement $\chi_{0}^{2}>\chi_{(\alpha, d f)}^{2}$ is met for rejecting hypothesis $\mathrm{H}_{2}$ on the independence between the countries and indicators of socially responsible behaviour of sales staff. In other words, the differences between the indicators are statistically significant depending on the country in which the retailers operate. These confirmed the research results by Koncar \& Maric (2015), Gugler \& Shi (2008), that the concept of corporate social responsibility is evaluated and applied differently in different countries. This difference is most evident between the countries and regions that are economically developed, unlike the transitional and poor countries. The rejection of the hypothesis is confirmed by the $P$-statistics, since $P=0,000$ $<0,01$. As is the null hypothesis $\mathrm{H}_{2}$ is rejected, the coefficient of contingency $C$ can be calculated (Table 5).

Symmetric Measures

Table 5

\begin{tabular}{|l|c|c|c|}
\hline & Cmax & Value & Approx. Sig \\
\hline Contingency Coefficient &, 979 &, 262 &, 003 \\
\hline
\end{tabular}

Contingency coefficient $\mathrm{C}=0,262$ and sig. $=0,003$ confirm a statistically significant correlation between the countries of the Western Balkans and indicators of corporate social responsibility. As the coefficient $C$ is closer to zero than Cmax, the conclusion is that the relationship of moderate intensity. However, is the sample of the Western Balkans is divided into two sub-samples (EU countries and not EU countries) and testing is done separately within these sub-samples, there are different observations (Table 6).

Table 6

Chi-Square tests (sub-sample: EU countries and not EU countries of WB)

\begin{tabular}{|l|c|c|c|c|}
\hline & Pearson Chi-Square & \multicolumn{2}{|c|}{$\chi_{(\alpha=0,01 ; 0,05 ; d f)}^{2}$} & P-value \\
\hline $\begin{array}{l}\text { Not EU } \\
\text { countries }\end{array}$ & $9,784^{*}$ & 26,217 & 21,026 &, $635^{*}$ \\
\hline $\begin{array}{l}\text { EU } \\
\text { countries }\end{array}$ & $1,323^{*}$ & 16,812 & 14,067 &, $970^{*}$ \\
\hline
\end{tabular}

$* \mathrm{H}_{2}$ is accepted

The table shows that the differences in the indicators of social responsibility within the sample of EU countries (Slovenia and Croatia) are random, i.e. the country in which analysed retailer operates does not affect the 
behaviour of sales staff, because the conditions $\chi_{0}^{2}=9,784$ $<\chi_{(\alpha, d f)}^{2}$ and $\mathrm{P}=0,635>0,05$ are met. The same is confirmed by the observation depending on the level of the second sub-sample of not EU countries (Serbia, Bosnia and Herzegovina and Montenegro) where the condition $\chi_{0}^{2}=1,323<\chi_{(\alpha, d f)}^{2}$ and $\mathrm{P}=0,970>0,05$ is met. Therefore, the conclusion is that within the economically, culturally and socially related countries, there are no significant differences in the perception of the indicators of social responsibility by customers. In other words, customers from Slovenia and Croatia identically value the analysed indicators, as well as, on the other hand, customers from Serbia, Bosnia and Herzegovina and Montenegro. This result suggests checking the latest research hypothesis $\mathrm{H}_{3}$ on independence of indicators from the regions of the EU and not EU countries within the Western Balkans. In testing hypothesis $\mathrm{H}_{3}$, indicators of social responsibility are set as dependent characteristics, while a group of EU countries, on the one hand, and a group of not EU countries, on the other hand are set as independent characteristics. The study on correlation between these two variables is done on the level of the entire sample of the Western Balkans. Necessary data are illustrated by the following Table 7.

Table 7

Chi-Square tests (the overall sample of the Western Balkans)

\begin{tabular}{|l|c|c|c|c|}
\hline & $\begin{array}{c}\text { Pearson Chi- } \\
\text { Square }\end{array}$ & \multicolumn{2}{|c|}{$\chi_{(\alpha=0,01 ; 0,05 ; d f)}^{2}$} & P-value \\
\hline Western Balkans & $61,945^{* *}$ & 16,812 & 12,592 &, $000^{* *}$ \\
\hline
\end{tabular}

$* * \mathrm{H}_{3}$ is rejected

Table 7 reads the value of Chi statistics $\chi_{0}^{2}=61,945$ which is above the limit value $\chi_{(\alpha, d f)}^{2}$ so the hypothesis $\mathrm{H}_{3}$ is rejected and it can be concluded that the differences between the indicators of social responsibility in the behaviour of sales staff are statistically significant, with respect to the group of Western Balkan countries that are members of the EU and are in the process of joining the EU. In other words, consumers from the Western Balkans in the EU evaluate indicators differently than the Western Balkans region that is in the process of joining the EU. Contingency coefficient indicates that the correlation between these variables is of high intensity $\mathrm{C}=0,9123$ and sig. $=0,000$ (Table 8$)$.

Symmetric Measures

Table 8

\begin{tabular}{|l|c|c|c|}
\hline & Cmax & Value & Approx. Sig \\
\hline Contingency Coefficient &, 9619 &, 9123 &, 000 \\
\hline
\end{tabular}

Conducted testing suggests the following conclusions: 1) Indicators of socially responsible behaviour of sales staff in the retail sector of the Western Balkans are independent from retailers, i.e. the differences that appear in the indicators are not statistically significant in relation to retailers where final purchase and sale are performed; 2) indicators show a statistically significant dependence on the countries, observed for the entire sample of the Western Balkans, 3) when the sample of the Western Balkans country is regrouped to more developed EU Member States (Slo. and Cro.) and transition countries that are not EU members (Srb., B\&H, Mne.), testing within these subsamples shows that there is no statistically significant correlation between the indicators and the analysed countries within a given sub-sample; 4) highest level of correlation between variables can be read when subsamples of EU countries and not EU countries are viewed as a whole, and when their correlation is tested with indicators of social responsibility at the level of the entire sample of the Western Balkans.

\section{Discussion}

Respondents' answers, the results of conducted testing and conclusions are the basis for defining three figures that will serve as a basis for discussion and analysis of the results: 1) The first graphical presentation $\left(\mathrm{GP}_{1}\right)$ includes indicators of social responsibility in the transition countries of the Western Balkans (not EU countries); 2) The second graphical presentation $\left(\mathrm{GP}_{2}\right)$ refers to the developed countries of the Western Balkans which are members of the EU, and 3) The third graphical presentation $\left(\mathrm{GP}_{3}\right)$ presents an overview of indicators at the level of the entire market of the Western Balkans. Ranking of indicators in the given graphical presentation is made using the extended Likert scale (Sullivan, 2007), which includes estimates of 1 minor impact to 7 very significant impact. The basis of the ranking were the respondents' answers (e.g.: the most frequent response gets the rank of 7 , the next 6 , and so on). Figure 1 presents the ranked indicators for not EU countries.

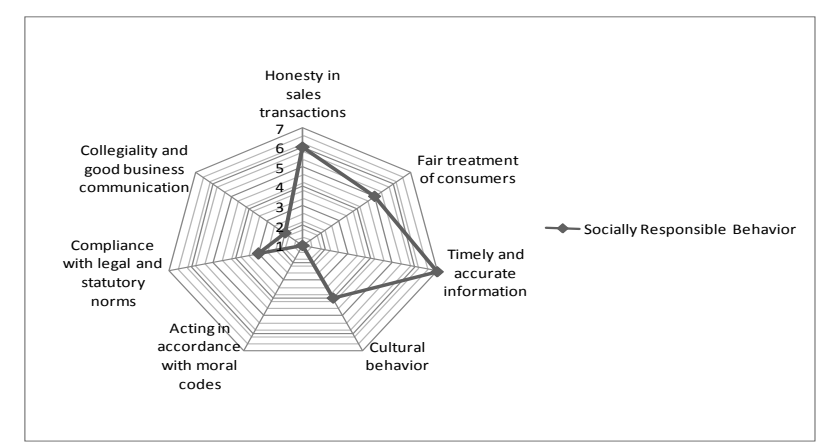

Figure 1 - $\mathrm{GP}_{1}-$ Graphical presentation of socially responsible behaviour of sales staff in the retail sector of the Western Balkans (sample not EU countries).

The ranking shows that a socially responsible salesperson in all regions and in entire not EU market of Western Balkans provides accurate and reliable information (rank 7). Such seller is trustworthy and reliable, and therefore potential consumers are sure that their choice will be good. This means that any information provided by sales staff prior to the act of purchase will be valid, accurate, not misleading and aimed at assisting the consumers in choosing a product. Described conduct of sales staff is highly ranked, considered as socially responsible, and results in a satisfied and loyal consumer. Honesty in sales transactions is also highly ranked throughout the region (rank 6). Consumers appreciate getting advice and any form of assistance from the sellers. Seller's social obligation is to treat consumers as equals, as the objective and purpose of the business relationship, and to treat them with respect and 
dignity. Only such a relationship builds honesty, trust and loyalty. The obtained results are consistent with the research done by Vemic-Djurkovic, Jotic \& Maric (2013), where honesty and trust is emphasized as the most important indicator that determines customer's choice and is directly reflected on the decision to buy in the services sector in the market of the Western Balkans. The indicator - Fair treatment of consumers is highly ranked (rank 5), which coincides with another important research conducted by McDonald \& Rundle-Thiele (2008), Nbudisi (2007) and Sankar \& Bhattacharya (2001) draw attention to timely and accurate information provided to potential consumers and polite attitude towards customers in the act of sale as the most important indicators of socially responsible behaviour of employees. Next in rank (rank 4) is indicator - Cultural behaviour, which implies that the social obligation of the seller is to respect the basic cultural norms and standards of conduct of a "good host", which according to Jones et al (2007) means that the social obligation of the seller is to observe the retailer as its own home and the customers as its guests. On the other hand, in this region, Legal norms with rank 3 are below the average. The results of NGO "Smart Kolektiv" in 2007 identify the lack of legislation in this particular area as the biggest threat to the implementation of the social responsibility concept in the Western Balkans market (Kuzmanovic \& Vukovic 2010). Low deviations are found for the indicators Collegiality and good business communication (rank 2) and Moral codes (rank 1). The reason for such low importance of these indicators is in failure to understand the essence and meaning of morality, business ethics and good business communication on the market of transition countries. There are no serious studies that emphasize their importance, and in addition there is no quality education of consumers by institutions, companies, associations for consumer protection, etc. Ranking of indicators is different when developed countries of the Western Balkan countries that are members of the EU are observed (Figure 2).

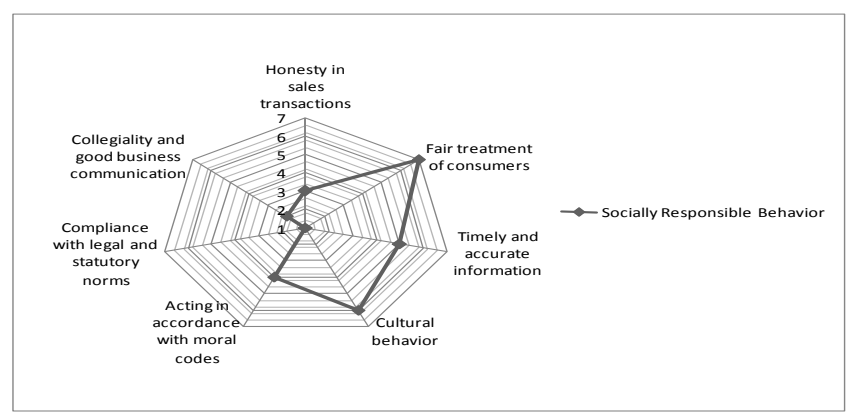

Figure $2-\mathrm{GP}_{2}-$ Graphical presentation of socially responsible behaviour of sales staff in the retail sector of the Western Balkans (sample of EU countries)

Figure 2 shows that the most important indicator of social responsibility is Fair treatment of consumers (rank 7). Unlike the transition countries, consumers in Slovenia and Croatia regard Fair treatment of consumers as a basic moral and social duty of any seller, which has a direct impact on the business success of the company. Such results are consistent with the results of related research (Ndubisi, 2007; Sankar \& Bhattacharya, 2001) that define seller's understanding, kindness and dedication to the as a factor that contributes significantly to increasing the satisfaction and loyalty of the final consumer. Second place belongs to indicator - Curtural behaviour (rank 6) i.e. respect for cultural norms and business etiquette in relation to customers. Both indicators are by two positions better ranked in comparison with transition countries, which coincides with the results of the research done by Koncar \& Maric (2015). They show that in the developed countries of the Western Balkans with their legal system in compliance with the legislative system of the EU, providing accurate and timely information (rank 5) and honesty in business transactions is simply implied, as it is regulated by the law. Customers from these countries define the most significant indicators those that are impossible to be covered by legislative policy and are a true reflection of the behaviour of sales staff, such as: fairness, kindness, honesty, and civility. Customers attach great importance to respecting and acting in accordance with moral codes. According to the results of numerous studies (Banejree, 2008, Molica et al. 2008, Nbudisi 2007), over $90 \%$ of trading companies have adopted codes of moral behaviour. At the bottom there are indicators of collegiality and good business communication (rank 2), and compliance with legal and statutory norms (rank 1). The reason for the low ranking of this indicator is the fact that acting under the law implies a duty itself. Thus, customers in developed countries believe that this indicator should not be discussed and give priority to other indicators as social responsibility involves much more than mere compliance with the law. Comprehensive overview of the ranked indicators on both levels of observation is illustrated by the figure below (Figure 3).

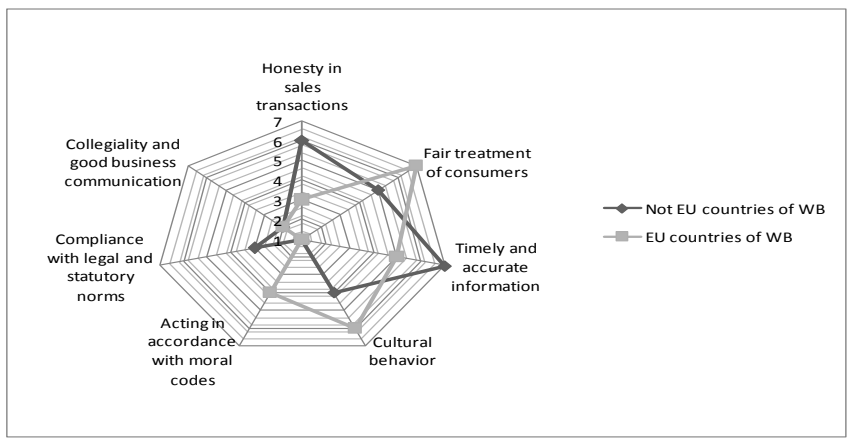

Figure 3- $\mathrm{GP}_{3}$ - Graphical presentation of socially responsible behaviour of sales staff in the retail sector of the Western Balkans.

The figure represents final ranking of indicators of socially responsible behaviour of sales staff in the retail sector in the Western Balkans countries. The graphical presentation $\left(\mathrm{GP}_{3}\right)$ is the result of market research of consumers in the biggest retail chains in the Western Balkans and as such provides a fair presentation of the indicators that are important for the promotion of social responsibility in the behaviour of sales staff and employees in the retail sector. This presentation should be mandatory general standard on the basis of which the management of retailers will create a climate of socially responsible culture and behaviour. The analysis should not omit the fact that the Western Balkans countries, which are not members of the EU, show cases of employees put under pressure by their managers to consciously violate these indicators of social responsibility, if it is assessed it will contribute to the survival of the company in the market. In such situations, 
employees are faced with a dilemma company's "good" vs. consumer's "good". Therefore, employees cannot be objective, and often are forced to consciously violate the indicators of social responsibility. Comparison of the research results shows that the most important indicators are Fair treatment of consumers and Timely and accurate information (avg. rank 6). The following ranking (avg. rank 5) attached to Cultural behaviour and Honesty in sales transaction (avg. rank 4.5). They are followed by Acting in accordance with moral codes with an average rank of 2.5 . The lowest significance is assigned to Compliance with legal and statutory standards (avg. rank 2) and Collegiality and good business communications (avg. rank 1.5).

\section{Conclusions}

The need for the study of social responsibility in the conduct of sales staff in Serbian supermarkets resulted from the fact that this segment of service is often regarded as key competitive advantage in the Western Balkans market (Koncar \& Maric 2015, Kuzmanovic \& Vukovic 2010). In this regard, the main objective of the research was to analyse and precisely define the impact of indicators of socially responsible behaviour of sales staff, such as honesty in sales transactions, fair relationship with the consumer, timely and accurate information, cultural behaviour, moral codes, respect of legal and statutory norms, collegiality and quality of business communication. In this context, a survey was conducted among consumers of the largest supermarkets in Western Balkans and the hypothesis was tested on independence of indicator of socially responsible behaviour of sales staff in retailers, countries and regions (EU countries and not EU countries). Testing confirmed the hypothesis on independence of indicators and retailers, while at the level of the region of EU countries and not EU countries, testing showed that the differences in the indicators are statistically significant depending on the region in which the retail is located. This can lead to the final answer to the research questions: $\mathrm{RQ}_{1}$ : the conclusion is that consumers in the Western Balkans differently value and accept specific indicators, $\mathrm{RQ}_{2}$ : differences in the indicators are significant between consumers living in the EU countries, who define as the most important indicators Fair relationship with consumers and Cultural behaviour, as opposed to consumers in not EU countries who ranked the most important indicators of Accurate and precise information and Fairness in the sales transactions, $\mathrm{RQ}_{3}$ : on the basis of these conclusions, the influence is ranked for the individual indicators of socially responsible behaviour of sales staff in the retail sector in the Western Balkan countries that are EU members $\left(\mathrm{GP}_{1}\right)$, transition countries that are in the process of joining the $\mathrm{EU}\left(\mathrm{GP}_{2}\right)$ and unified graphical presentation for the entire region $\left(\mathrm{GP}_{3}\right)$.

Conducted testing and obtained results are also significant in practice. It can assist management of trading companies in defining and creating socially responsible workplace and shaping loyal employees, which directly affects the profitability of supermarkets through meeting the needs, desires and interests of consumers better than their competitors do. Also, the supermarket management in the region of non EU countries should work on strengthening those indicators that are highly ranked in the EU countries, to make their companies better prepared for entry into the EU and their appearance on the market.

The disadvantage of the research is the limitation to the market of those five Western Balkan countries, as well as the survey technique which required respondents to choose between seven pre-specified indicators. Lack of research is due to the fact that only the seller - consumer correlation was analysed, i.e. broader context within companies is not included, such as, for example, the relation between management and employees, in terms of whether, and to what extent employees are put under pressure to behave (un)ethically, to violate the indicators of social responsibility, etc. The above was not included in the existing research because there is still no willingness of employees, particularly in transition countries, to participate in the research about the management - employee relation. In addition, the future research should include a larger sample of countries and make a comparison between the opinions of customers in the countries of Western Europe that are fully-fledged members of the EU (e.g. Germany, Spain, Italy, Austria, etc.) and the Western Balkans. In addition, future research should focus on defining subgroups within the indicators and how their influence is reflected on socially responsible behaviour. For instance, the study within the scope of indicator - Cultural behaviour should cover statistically significant influence of religion, family values, environment, social status, etc. Furthermore, future research should look into the reasons for deviations in the impact of certain indicators between regions, e.g. cultural norms of behaviour and moral codes in EU countries, honesty in sales transactions in not EU countries, and so on.

\section{References}

Andersen, M., \& Skjoett-Larsen, T. (2009). Corporate social responsibility in global supply chains. Supply Chain Management: An International Journal, 14(2), 75-86. http://dx.doi.org/10.1108/13598540910941948.

Becker-Olsen, K., Cudmore, A., \& Paul Hill, R. (2006). The impact of perceived corporate social responsibility on consumer behavior. Journal of Business Research, 59(1), 46-53. http://dx.doi.org/10.1016/j.jbusres.2005.01.001

Berber, N., Susnjar, G. S., Slavic, A., \& Baosic, M. (2014). Relationship between Corporate Social Responsibility and Human Resource Management - as new management concepts - in Central and Eastern Europe. Engineering Economics, 25(3), 360-369. http://dx.doi.org/10.5755/J01.EE.25.3.4222

Banejree, S. B. (2008). Corporate Social Responsibility: The Good, the Bad and the Ugly. Crit Sociol January, 34(1), 5179. http://dx.doi.org/10.1177/0896920507084623

Besley, T., \& Ghatak, M. (2007). Retailing Public Goods: The Economics of Corporate Social Responsibility. Journal of Public Economics, 91(9), 1645-1663. http://dx.doi.org/10.1016/J.JPUBECO.2007.07.006 
Castaldo, S., Perrini, F., Misani, N., \& Tencati, A. (2009). The missing link between corporate social responsibility and consumer trust: The case of fair trade products. Journal of Business Ethics, 84, 1-15. http://dx.doi.org/10.1007/S105 51-008-9669-4

Demetriades, F., \& Auret, C. J. (2014). Corporate social responsibility and firm performance in South Africa. S. Afr. J. Bus. Manage., 45(1), 1-13. Available from internet: http://thoughtprint.usb.ac.za/sajbm/Journals/SAJBM\%20Vol\%2045\%20Number\%201\%20March\%202014.pdf\#page=4

Dul, S., Bhattacharya, C. B., \& Sen, S. (2010). Maximizing Business Returns to Corporate Social Responsibility (CSR): The Role of CSR Communication. International Journal of Management Reviews, 12(1), 8-19. http://dx.doi.org/10. 1111/J.1468-2370.2009.00276.X

Eisenberg, M. A. (1999). Corporate law and social norms. Columbia Law Review, 99(5), 1253-1292. http://dx.doi.org/ $10.2307 / 1123456$

Garriga, M. (2004). Corporate Social Responsibility Theories: Mapping and Territory. Journal of Business Ethics, 53, 5171. http://dx.doi.org/10.1007/978-94-007-4126-3_4

Green, T., \& Peloza, J. (2014). How do consumers infer corporate social responsibility? The role of organization size. Journal of Consumer Behavior, 13(4), 282-293. http://dx.doi.org/10.1002/CB.1466

Gugler, P., \& Shi, J. J. (2009). Corporate Social Responsibility for Developing Country Multinational Corporations: Lost War in Pertaining Global Competitiveness. Journal of Business Ethics, 87(1), 3-24. http://dx.doi.org/10.1007/s10551008-9801-5

Johansson, T. S., \& Neilsen, A. E. (2012). CSR in corporate self-storying - legitimacy as a question of differentiation and conformity. Corporate Communications: An International Journal, 17(4), 434-448. http://dx.doi.org/10.1108/ 13563281211274130

Jones, P., Comfort, D., \& Hillier, D. (2007). Marketing and corporate social responsibility within food stores. British Food Journal, 109(8), 582-593. http://dx.doi.org/10.1108/00070700710772381

Kim, S. Y., \& Reber, B. H. (2008). Public relations' place in corporate social responsibility: Practitioners define their role. Public Relations Review, 34(4), 337-342. http://dx.doi.org/10.1016/j.pubrev.2008.07.003

Koncar, J., \& Maric, R. (2015). Job Satisfaction in Trade Sector: Evidence from the Retailers in the Largest Supermarkets of the Western Balkans. Revija za Socijalnu politiku, 22(3), 375-392. http://dx.doi.org/10.3935/rsp.v22i3.1268

Kuzmanovic, T. D., \& Vukovic, M. (2010). Corporate social responsibility in Serbia in the light of global crisis. Business School, 3, 32-40.

McDonald, L. M., \& Rundle-Thiele, S. (2008). Corporate social responsibility and bank consumer satisfaction: A research agenda. International Journal of Bank Marketing, 26(3), 170-182. http://dx.doi.org/10.1108/02652320810864643

Molica, D. G., Carvalho Neto, A., Goncalves, P. P. B. (2008) Corporate Social Responsibility: lost opportunities for workers and employers. Review of Business Management, 10(28), 215-233. https://doi.org/10.7819/rbgn.v10i28.205

Nbudisi, N. O. (2007). Relationship marketing and customer loyalty. Marketing Intelligence \& Planning, 25(1), 98-106. http://dx.doi.org/10.1108/02634500710722425

Patrus, R., Carvalho Neto, A. M., Coelho, H. M. Q., \& Sousa Teodosio, A. S. (2013) Corporate Social Responsibility and labor relations: a research agenda about internal stakeholders management in un's global compact signatory corporations. Review of Business Management, 15(46), 22-38. http://dx.doi.org/10.7819/rbgn.v15i46.1291

Salacuse, J. W. (1998). Ten ways that culture affects negotiating style: some survey results. Negotiation Journal, 14(3), 221-240. http://dx.doi.org/10.1111/J.1571-9979.1998.TB00162.X

Salmones, M. G., Crespo, A. H., \& Bosque, I. R. (2005). Influence of Corporate Social Responsibility on Loyalty and Valuation of Services. Journal of Business Ethics, 61(4), 369-385. http://dx.doi.org/10.1007/S10551-005-5841-2

Sankar, S., \& Bhattacharya, C. B. (2001). Does Doing Good Always Lead to Doing Better? Consumer Reactions to Corporate Social Responsibility. Journal of Marketing Research, 38(2), 225-243. http://dx.doi.org/10.1509/ JMKR.38.2.225.18838

Snider, J., Hill, R. P., \& Martin, D. (2003). Corporate social responsibility in the 21st century: a view from the world's most successful firm. Journal of Business Ethics, 48, 175-187. http://dx.doi.org/10.1023/B:BUSI.00000046 06.29523.DB

Sullivan, M. (2007). Statistics: Informed Decisions Using Data. New Jersey: Pearson Prentice Hall.

Vemic-Djurkovic, J., Jotic, J., \& Maric, R. (2013). A comparative analysis of contribution of human resource management to organizational performance of banks in Serbia. Industry, 41(4), 91-107. http://dx.doi.org/10.5937/INDU STRIJA41-4487.

The article has been reviewed.

Received in July, 2016; accepted in February, 2017. 